\title{
Scotland, the Caribbean
}

and the Atlantic World,

\section{0-1820}

D OUGLAS J. HAMILTON

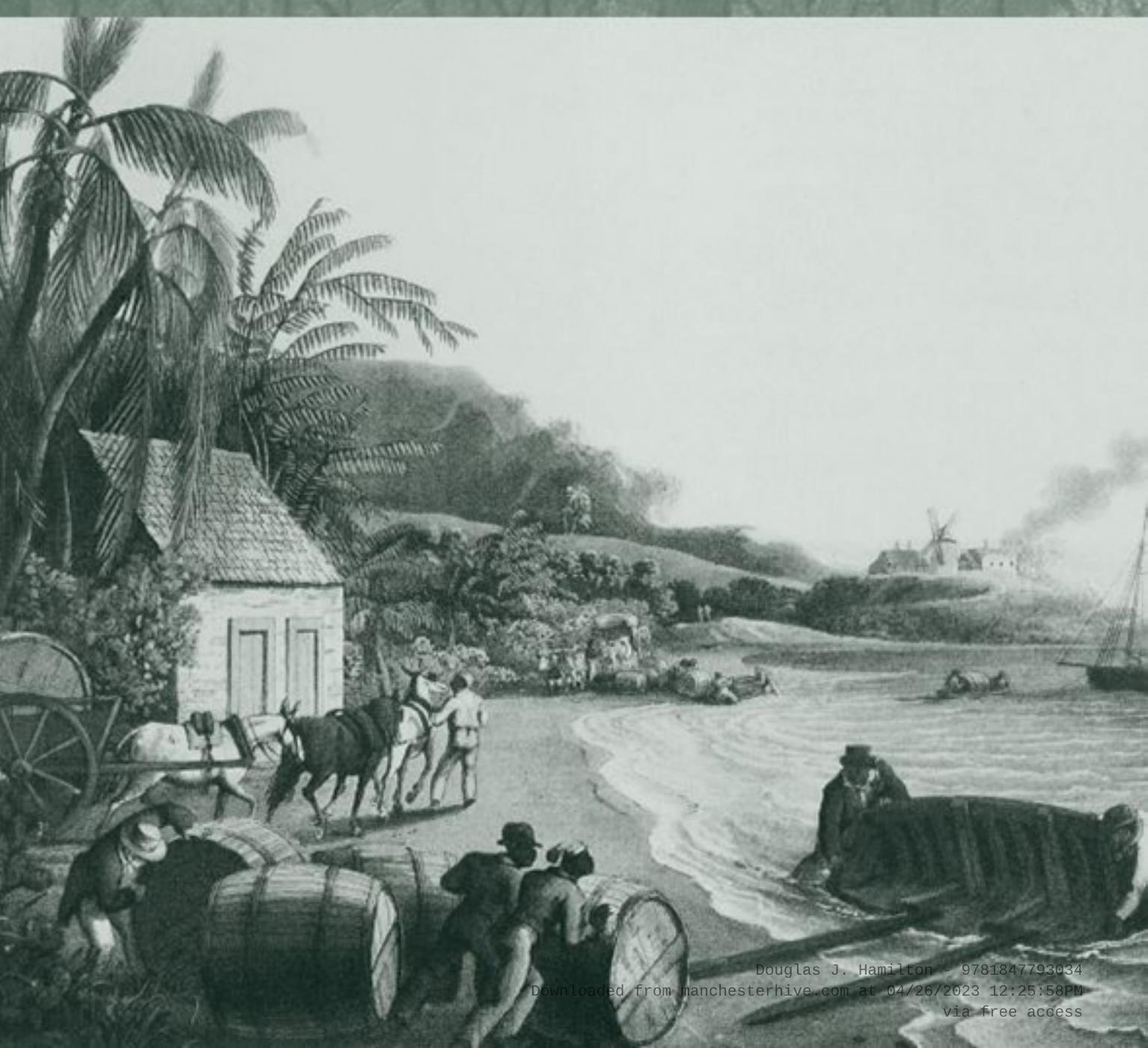




\section{-STUDIES IN- IMPERIALISM}

general editor John M. MacKenzie

When the 'Studies in Imperialism' series was founded more than twenty years ago, emphasis was laid upon the conviction that 'imperialism as a cultural phenomenon had as significant an effect on the dominant as on the subordinate societies'. With more than fifty books published, this remains the prime concern of the series. Crossdisciplinary work has indeed appeared covering the full spectrum of cultural phenomena, as well as examining aspects of gender and sex, frontiers and law, science and the environment, language and literature, migration and patriotic societies, and much else. Moreover, the series has always wished to present comparative work on European and American imperialism, and particularly welcomes the submission of books in these areas. The fascination with imperialism, in all its aspects, shows no sign of abating, and this series will continue to lead the way in encouraging the widest possible range of studies in the field. 'Studies in Imperialism' is fully organic in its development, always seeking to be at the cutting edge, responding to the latest interests of scholars and the needs of this ever-expanding area of scholarship.

\section{Scotland, the Caribbean and the Atlantic world, $1750-1820$}

MANCHESTER 1824

Manchester University Press 


\section{AVAILABLE IN THE SERIES}

\section{CULTURAL IDENTITIES AND THE AESTHETICS OF BRITISHNESS ed. Dana Arnold BRITAIN IN CHINA \\ Community, culture and colonialism, 1900-1949 Robert Bickers NEW FRONTIERS \\ Imperialism's new communities in East Asia 1842-1952 eds Robert Bickers and Christian Henriot \\ THE ARCTIC IN THE BRITISH IMAGINATION 1818-1914 Robert G. David \\ IMPERIAL CITIES Landscape, display and identity eds Felix Driver and David Gilbert \\ SCIENCE AND SOCIETY IN SOUTHERN AFRICA ed. Saul Dubow EQUAL SUBJECTS, UNEQUAL RIGHTS \\ Indigenous peoples in British settler colonies, 1830s-1910 \\ Julie Evans, Patricia Grimshaw, David Phillips and Shurlee Swain EMIGRANT HOMECOMINGS \\ The return movement of emigrants, 1600-2000 Marjory Harper \\ EMPIRE AND SEXUALITY \\ The British experience Ronald Hyam REPORTING THE RAJ \\ The British press in India, c. 1880-1922 Chandrika Kaul \\ SILK AND EMPIRE Brenda M. King \\ LAW, HISTORY, COLONIALISM}

The reach of empire eds Diane Kirkby and Catherine Coleborne

THE SOUTH AFRICAN WAR REAPPRAISED ed. Donal Lowry

PROPAGANDA AND EMPIRE

The manipulation of British public opinion, 1880-1960 John M. MacKenzie THE OTHER EMPIRE

Metropolis, India and progress in the colonial imagination John Marriott GUARDIANS OF EMPIRE

The armed forces of the colonial powers, c. 1700-1964 eds David Omissi and David Killingray

FEMALE IMPERIALISM AND NATIONAL IDENTITY

Imperial Order Daughters of the Empire Katie Pickles MARRIED TO THE EMPIRE

Gender, politics and imperialism in India, 1883-1947 Mary A. Procida IMPERIAL PERSUADERS

Images of Africa and Asia in British advertising Anandi Ramamurthy IMPERIALISM AND MUSIC

Britain 1876-1953 Jeffrey Richards COLONIAL FRONTIERS

Indigenous-European encounters in settler societies ed. Lynette Russell

West Indian intellectuals in Britain ed. Bill Schwarz MIGRANT RACES

Empire, identity and K. S. Ranjitsinhji Satadru Sen

THE VICTORIAN SOLDIER IN AFRICA Edward M. Spiers MARTIAL RACES AND MASCULINITY IN THE BRITISH ARMY, 1857-1914 Heather Streets

THE FRENCH EMPIRE BETWEEN THE WAR Imperialism, politics and society Martin Thomas BRITISH CULTURE AND THE END OF EMPIRE ed. Stuart Ward 


\section{Scotland, \\ the Caribbean and \\ the Atlantic world \\ 1750-1820}

Douglas J. Hamilton

MANCHESTER

UNIVERSITY PRESS

Manchester and New York

distributed exclusively in the USA by PALGRAVE 
Copyright (C) Douglas J. Hamilton 2005

The right of Douglas J. Hamilton to be identified as the author of this work has been asserted by him in accordance with the Copyright, Designs and Patents Act 1988.

\section{Published by MANCHESTER UNIVERSITY PRESS}

OXFORD ROAD, MANCHESTER M13 9NR, UK

and ROOM 400, 175 FIFTH AVENUE, NEW YORK, NY 10010, USA

Www.manchesteruniversitypress.co.uk

Distributed exclusively in the USA by

\section{PALGRAVE}

175 FIFTH AVENUE, NEW YORK, NY 10010, USA

Distributed exclusively in Canada by

UBC PRESS

UNIVERSITY OF BRITISH COLUMBIA,

2029 WEST MALL, VANCOUVER, BC, CANADA V6T 1 Z2

British Library Cataloguing-in-Publication Data

A catalogue record for this book is available from the British Library

Library of Congress Cataloging-in-Publication Data applied for

ISBN 0719071828 hardback

EAN 9780719071829

First published 2005

$14131211100908070605 \quad 1098876554321$

The publisher has no responsibility for the persistence or accuracy of URLs for any external or third-party internet websites referred to in this book, and does not guarantee that any content on such websites is, or will remain, accurate or appropriate.

Typeset in Trump Mediaeval

by SNP Best-set Typesetter Ltd., Hong Kong 